\title{
Penyisihan Fluoride dan COD Air Limbah Industri Asam Fosfat Menggunakan Kombinasi Presipitasi dan Elektrokoagulasi
}

\section{Adhi Setiawan*, Nadya Ayu Arianingtyas, Novi Eka Mayangsari, Tanti Utami Dewi}

\author{
Program Studi Teknik Pengolahan Limbah \\ Jurusan Teknik Permesinan Kapal, Politeknik Perkapalan Negeri Surabaya \\ Jl. Teknik Kimia Kampus ITS Sukolilo Surabaya, Indonesia \\ Email: adhistw23@gmail.com
}

\begin{abstract}
Abstrak
Proses produksi asam fosfat menghasilkan air limbah dengan kandungan fluoride dan Chemical Oxygen Demand (COD) yang berpotensi mencemari lingkungan jika tidak diolah secara tepat. Kandungan ion fluoride di dalam air dapat menjadi ancaman serius bagi kesehatan manusia karena menyebabkan kerusakan pada gigi dan tulang. Kombinasi presipitasi dan elektrokoagulasi merupakan salah satu alternatif yang efektif untuk menurunkan kandungan fluoride dan COD. Penelitian ini bertujuan menganalisis pengaruh $\mathrm{pH}$ presipitasi, tegangan, dan waktu kontak terhadap penyisihan fluoride dan COD pada limbah industri fosfat menggunakan metode presipitasi dan elektrokoagulasi. Proses presipitasi dan elektrokoagulasi dilakukan secara batch. Presipitan menggunakan bahan berupa $\mathrm{Ca}\left(\mathrm{OH}_{2}\right.$ sedangkan proses elektrokoagulasi menggunakan elektroda aluminium yang tersusun secara monopolar. Pengaturan pH presipitasi menggunakan $\mathrm{pH}$ 5, 7, dan 9. Elektrokoagulasi menggunakan variasi waktu kontak 40, 50, dan 60 menit. Variasi tegangan listrik 17, 22, dan $27 \mathrm{~V}$. Hasil penelitian menunjukkan bahwa peningkatan pH meningkatkan efisiensi penyisihan pada proses presipitasi. Peningkatan nilai tegangan listrik dan waktu kontak menyebabkan peningkatan efisiensi penyisihan fluoride dan COD. Efisiensi tertinggi pada proses penyisihan fluoride dan COD diperoleh pada kondisi pH 9, waktu kontak 60 menit dan tegangan 27 volt dengan nilai efisiensi penyisihan fluoride sebesar 99,84\% dan efisiensi penyisihan COD sebesar 56,35\%.
\end{abstract}

Kata kunci : Elektrokoagulasi, Presipitasi, Fluoride, COD, Asam fosfat

\section{Abstract \\ Removal of Fluoride and COD in Phosphoric Acid Industrial Wastewater Using Combination Precipitation and Electrokoagulation}

The production process of phosphoric acid produces wastewater containing fluoride and $C O D$ which has the potential to pollute the environment if not treated properly. The content of fluoride ions in water can be a serious threat to human health because it causes damage to teeth and bones. The combination of precipitation and electrocoagulation is an effective alternative to reduce fluoride and COD content. This study aims to analyze the effect of $\mathrm{pH}$ of precipitation, voltage, and contact time on fluoride and COD removal in industrial phosphate waste using precipitation and electrocoagulation methods. The precipitation and electrocoagulation processes are carried out in batches. Precipitant uses a material in the form of $\mathrm{Ca}(\mathrm{OH}) 2$, while the electrocoagulation process uses aluminum electrodes that are arranged monopolarly. Setting the $\mathrm{pH}$ of the precipitation using $\mathrm{pH} 5,7$, and 9. Electrocoagulation using a variation of contact time 40, 50, and 60 minutes. Electric voltage variations 17,22 , and $27 \mathrm{~V}$. The results showed that increasing $\mathrm{pH}$ increased the removal efficiency in the precipitation process. Increasing the value of the power supply voltage and contact time led to an increase in the efficiency of fluoride and COD removal. The highest efficiency in fluoride and COD removal 
process was obtained at conditions of $\mathrm{pH} 9$, contact time of 60 minutes and a voltage of 27 volts with a fluoride removal efficiency value of $99.84 \%$ and COD removal efficiency of $56.35 \%$.

\section{Keywords : Electrocoagulation, Presipitation, Fluoride, COD, Phosphoric acid}

\section{PENDAHULUAN}

Industri asam fosfat merupakan industri yang memproduksi asam fosfat dengan menggunakan bahan baku utama berupa batuan fosfat dan asam sulfat. Reaksi kimia antara batuan fosfat dan asam sulfat sehingga mengasilkan produk berupa asam fosfat, asam fluoride, dan gipsum. Produk utama asam fosfat merupakan bahan baku penting di dalam industri pupuk, industri karbon aktif, industri farmasi, dan industri kimia lainnya (Nawghare et al., 2001). Industri asam fosfat merupakan sumber penghasil air limbah dengan kandungan flouride yang tinggi serta bersifat asam. Air limbah yang dihasilkan dari industri asam fosfat bersumber dari blowdown proses SWC (Shutdown Water Cleaning) di unit Phosporic Acid Plant (PA), kondensat steam di unit Shulpuric Acid Plant (SA), dan air dari pencucian gypsum di unit purifikasi. Pembuangan air limbah tersebut secara langsung tanpa proses pengolahan menyebabkan peningkatan konsentrasi ion fluoride di badan air sehingga berpotensi menyebabkan pencemaran pada lingkungan akuatik dan air tanah (Wang et al., 2019). Beberapa penelitian telah melaporkan bahwa beberapa jenis seperti industri pembuatan kaca dan industri pembuatan bahan semikonduktor mengasilkan air limbah dengan kandungan fluoride pada konsentrasi yang tinggi (Toyoda dan Taira, 2000)

Keberadaan ion fluoride di dalam air dapat menjadi ancaman serius bagi kesehatan manusia (Huang et al., 2016). Konsentrasi fluoride yang terkandung di dalam limbah cair industri dapat mencapai ratusan bahkan sampai dengan ribuan miligram per liter dan telah melebihi batas yang telah ditetapkan organisasi kesehatan WHO sebesar $1,5 \mathrm{mg} / \mathrm{L}$ di dalam air minum (Tang et al., 2016; Emamjomeh et al., 2011). Negara USA menetapkan batasan standard konsentrasi fluoride di dalam air minum sebesar 0,6-0,9 $\mathrm{mg} / \mathrm{L}$. Peningkatan konsentrasi fluoride pada air minum melebihi $4 \mathrm{mg} / \mathrm{L}$ dapat menyebabkan fluorosis. Konsentrasi fluoride yang tinggi dapat menyebabkan deformasi tulang, kerusakan gigi, memar pada organ tiroid, hati, dan organ-organ lainnya (Changmai et al., 2018).

Beberapa metode yang dapat digunakan untuk menghilangkan kandungan flouride di dalam air limbah antara lain metode presipitasi kimia, koagulasi flokulasi, adsorpsi, reverse osmosis, membran filtrasi, dan elektrokoagulasi (Emammojeh et al., 2011; Huang et al., 2016). Beberapa bahan kimia seperti $\mathrm{CaCl}_{2}$ dan $\mathrm{CaO}$ seringkali digunakan sebagai proses presipitasi fluoride di dalam air limbah. Zeng et al. (2019) pada penelitian menggunakan $\mathrm{CaCl}_{2}$ untuk menyisihkan parameter fluoride pada air limbah artifisial. Penggunaan dosis $0,84 \mathrm{~g} / \mathrm{L} \mathrm{CaCl}$ dengan konsentrasi awal fluoride $400 \mathrm{mg} / \mathrm{L}$ dapat menghasilkan efisiensi penyisihan fluoride sebesar 95,73\%. Penggunaan koagulan kimia seperti poliferri sulfat dan polialuminium sulfat dapat menurunkan kandungan fluoride di dalam air limbah. Namun penggunaan koagulan tunggal hanya menghasilkan efisiensi penyisihan fluoride yang rendah sekitar 10-30\%. Selain itu, kebutuhan koagulan kimia, produksi sludge yang sangat tinggi serta membutuhkan proses preparasi kimia, lahan menjadi kekurangan dari proses pengolahan secara koagulasi flokulasi. Metode adsorbsi cukup efektif digunakan untuk menyisihkan flouride di dalam air limbah pada konsentrasi yang rendah. Pada air limbah dengan konsentrasi flouride yang tinggi diperlukan perlakuan awal presipitasi kimia untuk menurunkan konsentrasi fluoride sebelum proses adsorpsi. Selain itu, diperlukan regenerasi adsorben yang menyebabkan peningkatan biaya operasi peralatan (Budyanto et al. 2015). Proses pengolahan menggunakan reverse osmosis dan membran filtrasi dapat menurunkan konsentrasi flouride pada air limbah namun memerlukan tekanan operasi yang tinggi, waktu pengolahan yang lama, serta biaya operasi yang mahal (Das dan Nandi, 2020). 
Pada umumnya penelitian sebelumnya dilakukan dengan menggunakan metode tunggal dalam menurunkan konsentrasi fluoride di dalam air limbah. Penggunaan metode kombinasi presipitasi dan elektrokoagulasi dapat menjadi alternatif untuk mengolah air limbah dengan konsentrasi fluoride serta COD yang tinggi. Metode tersebut menggunakan presipitan $\mathrm{Ca}(\mathrm{OH})_{2}$ yang relatif murah namun cukup efektif dalam mengendapkan fluoride dalam bentuk $\mathrm{CaF}_{2}$. Hasil pengolahan secara presipitasi dilanjutkan dengan elektrokoagulasi sehingga diperoleh efisiensi penyisihan yang tinggi. Selain itu, proses elektrokoagulasi memilki kelebihan antara lain efisiensi proses pengolahan tinggi, biaya operasi yang murah, serta menghasilkan sedikit residu (Changmai et al. 2018; Drouiche et al. 2012). Penelitian ini bertujuan untuk menganalisis pengaruh $\mathrm{pH}$ presipitasi, tegangan, dan waktu kontak terhadap penyisihan parameter fluoride dan COD pada limbah industri fosfat menggunakan metode presipitasi dan elektrokoagulasi.

\section{METODOLOGI}

Limbah cair yang diperoleh dari pit limbah cair industri asam fosfat. Sampling air limbah tersebut dilakukan sebanyak satu kali pengambilan dengan volume total air limbah sebesar 300 L. Bahan kimia presipitan menggunakan padatan $\mathrm{Ca}(\mathrm{OH})_{2}$ (SAP 99\%). Akuades sebagai pelarut padatan $\mathrm{Ca}(\mathrm{OH})_{2}$.

Peralatan yang digunakan pada penelitian ini antara lain $\mathrm{pH}$ meter, timbangan analitik (Shimadzu AY 220), sumber tegangan DC 0-60 V 3A (Zhaoxin), spektrofotometer UV Vis (Agilent Cary 60), reaktor presipitasi dan reaktor elektrokoagulasi masing-masing berdimensi 25 $\mathrm{cm} \times 25 \mathrm{~cm} \times 20 \mathrm{~cm}$. Bahan reaktor terbuat dari akrilik dengan tebal $5 \mathrm{~mm}$. Reaktor presipitasi dilengkapi pengaduk dari baja tahan karat dan memiliki motor pengaduk dengan kecepatan 100 rpm. Gambar 1 menunjukkan desain reaktor elektrokoagulasi. Reaktor elektrokoagulasi terdiri dari empat pasang plat anoda dan katoda dari aluminium dengan dimensi 10×20 cm (Gambar 1).

\section{Proses Presipitasi-Elektrokoagulasi}

Proses pengolahan air limbah industri asam fosfat dilakukan menggunakan reaktor presipitasi dan elektrokoagulasi yang dioperasikan secara batch. Sebanyak $10 \mathrm{~L}$ air limbah dimasukkan ke dalam reaktor presipitasi dan ditambahkan dengan larutan $\mathrm{Ca}(\mathrm{OH})_{2}$ dengan konsentrasi $25 \%$ wt. Proses reaksi presipitasi dilakukan selama 20 menit dengan kecepatan pengadukan $100 \mathrm{rpm}$. Variasi $\mathrm{pH}$ proses presipitasi sebesar 5,7, dan 9. Limbah yang telah dipresipitasi diendapkan selama 30 menit dan air hasil olahan selanjutnya dimasukkan ke reaktor elektrokoagulasi. Proses elektrokoagulasi dilakukan selama waktu 40, 50, dan 60 menit Variasi tegangan proses elektrokoagulasi sebesar 17, 22, dan 27 V. Jarak antar anoda diatur $1 \mathrm{~cm}$ dan hubungan elektroda ke sumber DC dilakukan secara monopolar.

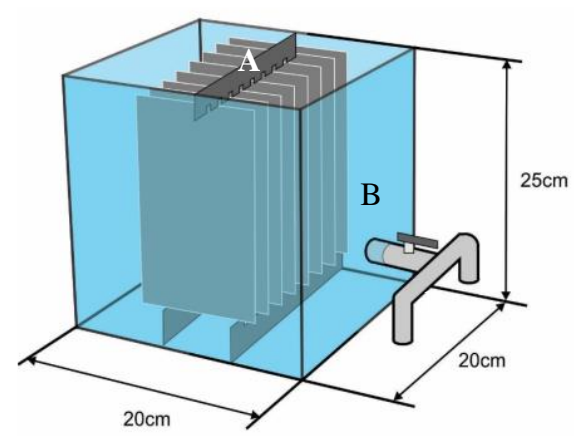

Gambar 1. Reaktor Elektrokoagulasi

Keterangan: $A=$ motor pengaduk; $B=$ kran sampling

\section{Pengujian Air Limbah}

Pengujian parameter pencemar air limbah meliputi parameter $\mathrm{pH}$, fluoride, dan COD. Pengujian parameter $\mathrm{pH}$ menggunakan SNI 066989.11-2004. Pengujian parameter fluoride menggunakan spektrofotometer berdasarkan SNI 06-6989.29-2005. Pengujian parameter COD menggunakan metode refluks tertutup berdasarkan SNI 6989.73:2009. Tabel 1 menunjukkan karakteristik air limbah industri asam fosfat. Hasil pengujian karakteristik air limbah selanjutnya dibandingkan Peraturan Gubernur Jawa Timur Nomor 52 Tahun 2014 Tentang Baku Mutu Air Limbah Bagi Industri Dan/Atau Kegiatan Usaha Lainnya Di Jawa Timur. Hasil pengujian menunjukkan bahwa konsentrasi fluoride dari industri asam fosfat telah melebihi baku mutu sehingga harus dilakukan pengolahan demi menjaga kestabilan lingkungan. 
Tabel 1. Karakteristik Infuent Air Limbah Industri Asam Fosfat

\begin{tabular}{lccc}
\hline Parameter & Satuan & Hasil Uji & Baku Mutu \\
\hline $\mathrm{pH}$ & - & 2,3 & $6-9$ \\
Fluoride & $\mathrm{mg} / \mathrm{L}$ & 1470,46 & 50 \\
COD & $\mathrm{mg} / \mathrm{L}$ & 25,5 & 200 \\
\hline
\end{tabular}

Pengujian parameter air limbah dilakukan sebelum dan setelah proses presipitasi-adsorbsi. Besarnya efisiensi penyisihan parameter fluoride dan COD sebelum dan setelah proses presipitasielektrokoagulasi dapat dihitung dengan persamaan :

$$
\text { Efisiensi_Penyisihan }=\frac{C_{0}-C_{f}}{C_{o}} 100 \%
$$

Keterangan: $C_{o}=$ konsentrasi awal $(\mathrm{mg} / \mathrm{L}) ; C_{f}=$ konsentrasi akhir ( $\mathrm{mg} / \mathrm{L})$

\section{HASIL DAN PEMBAHASAN}

\section{Presipitasi dengan $\mathrm{Ca}(\mathrm{OH})_{2}$}

Efisiensi penyisihan fluoride meningkat seiring dengan peningkatan $\mathrm{pH}$. Hasil penelitian menunjukkan bahwa efisiensi penyisihan maksimal fluoride diperoleh pada kondisi $\mathrm{pH} 9$ dengan nilai sebesar 92,77\% (Gambar 2). Hal tersebut sesuai dengan penelitian Atia dan Hoggui (2013) yang melaporkan bahwa Peningkatan $\mathrm{pH}$ mengarah pada peningkatan konsentrasi ion $\mathrm{Ca}^{2+}$ yang terlarut, sehingga menyebabkan reaksi presipitasi fluoride menjadi lebih sempurna. Hal tersebut menyebabkan efisiensi penyisihan fluoride meningkat saat $\mathrm{pH}$ dinaikkan. Hasil penelitian yang serupa telah dilakukan oleh Ezzedine et al. (2014) yang menunjukkan bahwa peningkatan $\mathrm{pH}$ larutan menggunakan lime pada $\mathrm{pH}$ 6,8-9 menyebabkan peningkatan efisiensi penyisihan fluoride meningkat sampai dengan $95 \%$.

Reaksi antara ion fluoride dan $\mathrm{Ca}(\mathrm{OH})_{2}$ terjadi melalui mekanisme persamaan reaksi kimia (2). Senyawa $\mathrm{CaF}_{2}$ di dalam air akan membentuk sistem kesetimbangan sebagaimana pada persamaan reaksi (2). $\mathrm{CaF}_{2}$ yang terbentuk saat presipitasi bersifat insoluble sehingga mudah dipisahkan dengan pengendapan. Pembentukan endapan $\mathrm{CaF}_{2}$ terbentuk disebabkan oleh nilai Ksp $\mathrm{CaF}_{2}$ yang rendah sehingga larutannya bersifat lewat jenuh (Wang et al. 2019).

$$
\mathrm{Ca}(\mathrm{OH})_{2(\text { (aq) }}+2 \mathrm{HF}_{(\mathrm{aq})} \rightarrow \mathrm{CaF}_{2} \downarrow_{(\mathrm{s})}+2 \mathrm{H}_{2} \mathrm{O}
$$

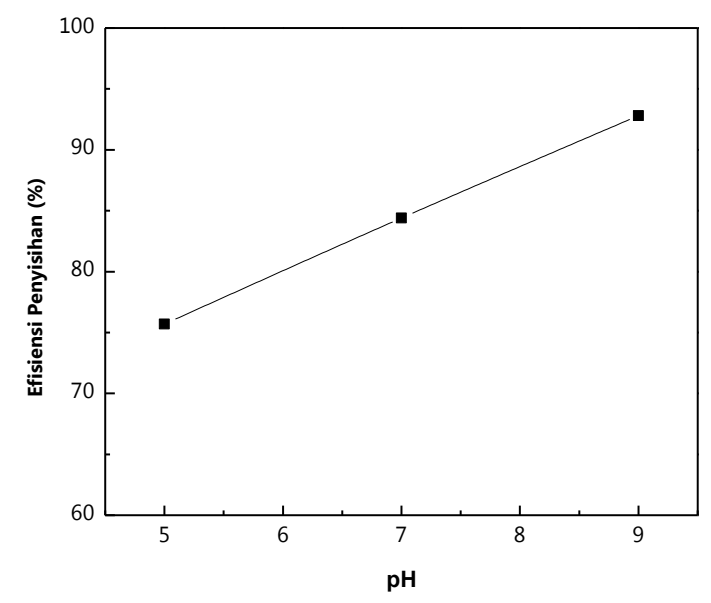

Gambar 2. Pengaruh $\mathrm{pH}$ terhadap penyisihan fluoride

\section{Elektrokoagulasi}

Gambar 3 menunjukkan pengaruh waktu kontak dan tegangan elektrokoagulasi terhadap efisiensi penyisihan fluoride di dalam air limbah. Hasil penelitian menunjukkan bahwa peningkatan waktu kontak dan tegangan menghasilkan peningkatan efisiensi penyisihan fluoride. Hal ini disebabkan peningkatan waktu kontak dan tegangan menyebabkan oksidasi elektroda alumunium meningkat sehingga meningkatkan konsentrasi $\mathrm{Al}(\mathrm{OH})_{3}$. Berdasarkan Hukum Faraday I menunjukkan bahwa zat terlarut yang dihasilkan pada suatu elektroda pada proses elektrokoagulasi sebanding dengan kuat arus listrik yang digunakan. Peningkatan tegangan listrik menyebabkan terjadinya kenaikan kuat arus sehingga meningkatkan laju oksidasi dari elektroda aluminium.

Proses elektrokoagulasi menghasilkan sejumlah reaksi elektrokimia yang menghasilkan senyawa aluminium hidroksil berbentuk monomer dan polimer yang selanjutnya terhidrolisis menghasilkan senyawa amorf $\mathrm{Al}(\mathrm{OH})_{3}$ (Silva et al., 2018). Berbagai reaksi kimia yang terjadi pada proses elektrokoagulasi limbah fluoride dengan elektroda aluminium sebagaimana pada persamaan reaksi (3) sampai dengan (8) sebagai berikut (Das dan Nandi, 2018):

$$
\begin{aligned}
& \mathrm{Al}_{(\mathrm{s})} \rightarrow \mathrm{Al}^{3+}{ }_{(\text {aq })}+3 \mathrm{e}^{-}{ }_{(\mathrm{aq})} \\
& 2 \mathrm{H}_{2} \mathrm{O}_{(\mathrm{l})}+2 \mathrm{e}^{-} \rightarrow \mathrm{H}_{2(\mathrm{~g})}+2 \mathrm{OH}^{-}{ }_{(\mathrm{aq})}
\end{aligned}
$$


$\mathrm{Al}^{3+}{ }_{(\mathrm{aq})}+\mathrm{H}_{2} \mathrm{O}_{(\mathrm{l})} \rightarrow \mathrm{Al}(\mathrm{OH})^{2+}{ }_{(\mathrm{aq})}+\mathrm{H}^{+}{ }_{(\mathrm{aq})}$

$\mathrm{Al}(\mathrm{OH})^{2+}{ }_{(\mathrm{aq})}+\mathrm{H}_{2} \mathrm{O}_{(\mathrm{l})} \rightarrow \mathrm{Al}(\mathrm{OH})_{2}{ }^{+}+\mathrm{H}^{+}{ }_{(\mathrm{aq})}$

$\mathrm{Al}(\mathrm{OH})_{2}{ }_{(\mathrm{aq})}+\mathrm{H}_{2} \mathrm{O}_{(\mathrm{l})} \rightarrow \mathrm{Al}(\mathrm{OH})_{3(\mathrm{~s})}+\mathrm{H}^{+}{ }_{(\mathrm{aq})}$

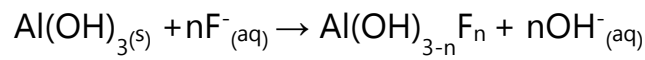

Pelat anoda aluminium yang teroksidasi menjadi ion $\mathrm{Al}^{3+}$ berfungsi sebagai koagulan dalam air limbah. Ion $\mathrm{Al}^{3+}$ yang dihasilkan akan mendestabilisasi polutan dalam air limbah sehingga kontaminan fluoride dapat dipisahkan. Berdasarkan persamaan reaksi kimia (3) sampai dengan (8) maka peningkatan konsentrasi $\mathrm{Al}(\mathrm{OH})_{3}$ akibat oksidasi aluminium menyebabkan jumlah sweep flocs yang terbentuk semakin tinggi sehingga jumlah fluoride yang diendapkan dalam bentuk $\mathrm{Al}(\mathrm{OH})_{3-n} \mathrm{~F}_{n}$ semakin banyak. Das dan Nandi (2018) melaporkan bahwa senyawa kompleks hidroksida logam yang terbentuk pada proses elektrokoagulasi memiliki afinitas yang

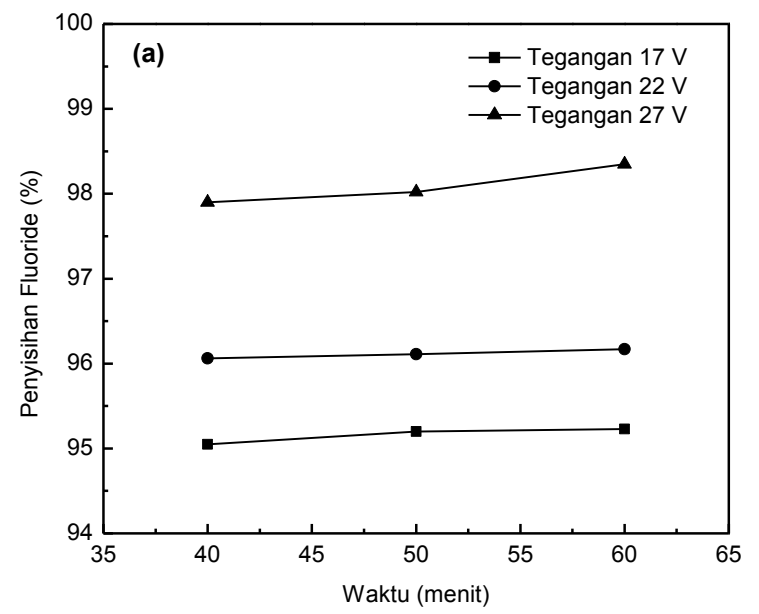

kuat dalam menyerap ion fluoride serta memiliki luas permukaan yang besar sehingga kontaminan dapat segera dipisahkan setelah proses elektrokoagulasi.

$\mathrm{pH}$ dalam proses elektrokoagulasi memiliki peranan yang penting dalam menyisihkan parameter kontaminan. Berdasarkan Gambar 3 menunjukkan bahwa peningkatan $\mathrm{pH}$ mulai 5 sampai dengan 9 menyebabkan peningkatan efisiensi penyisihan fluoride. Hal tersebut disebabkan pada $\mathrm{pH}$ asam kehadiran ion $\mathrm{H}^{+}$di dalam larutan menghambat pembentukan $\mathrm{Al}(\mathrm{OH})_{3}$. Namun, pada $\mathrm{pH}$ basa jumlah ion hidroksida yang dihasilkan mampu mendorong pembentukan flok $\mathrm{Al}(\mathrm{OH})_{3}$ yang dapat mengikat ion fluoride (Doggaz et al., 2018). Efisiensi penyisisihan ion fluoride maksimum diperoleh pada kondisi waktu kontak 60 menit, tegangan 27 $\mathrm{V}$, dan $\mathrm{pH} 9$ dengan nilai sebesar $99,84 \%$.

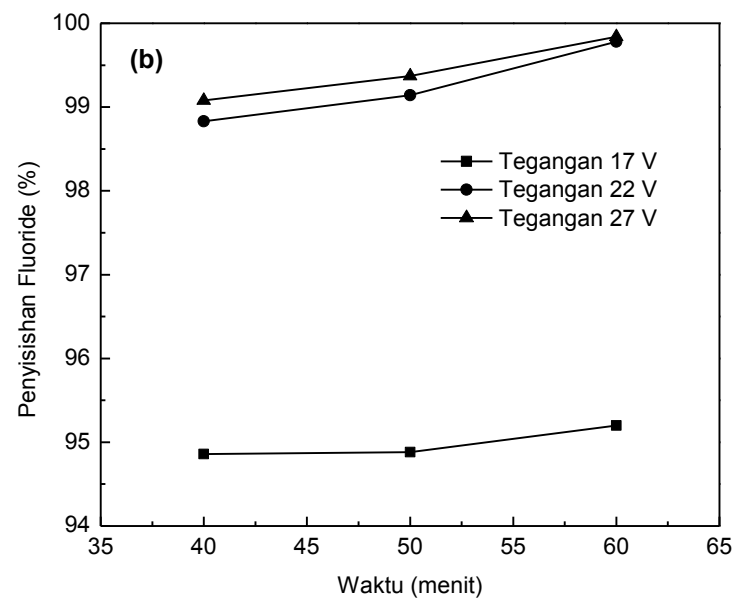

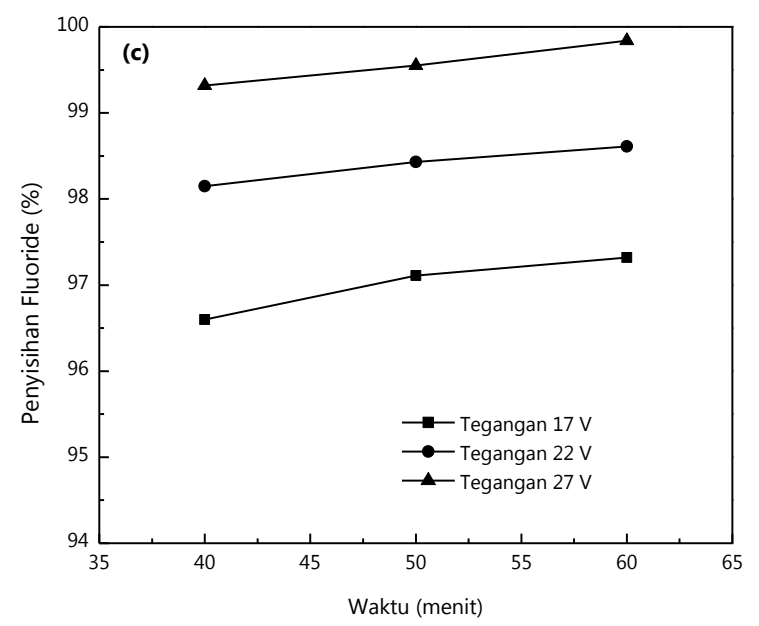

Gambar 3. Pengaruh waktu dan tegangan terhadap penyisihan fluoride (a) $\mathrm{pH} 5$ (b) $\mathrm{pH} 7$ dan $\mathrm{pH} 9$ 

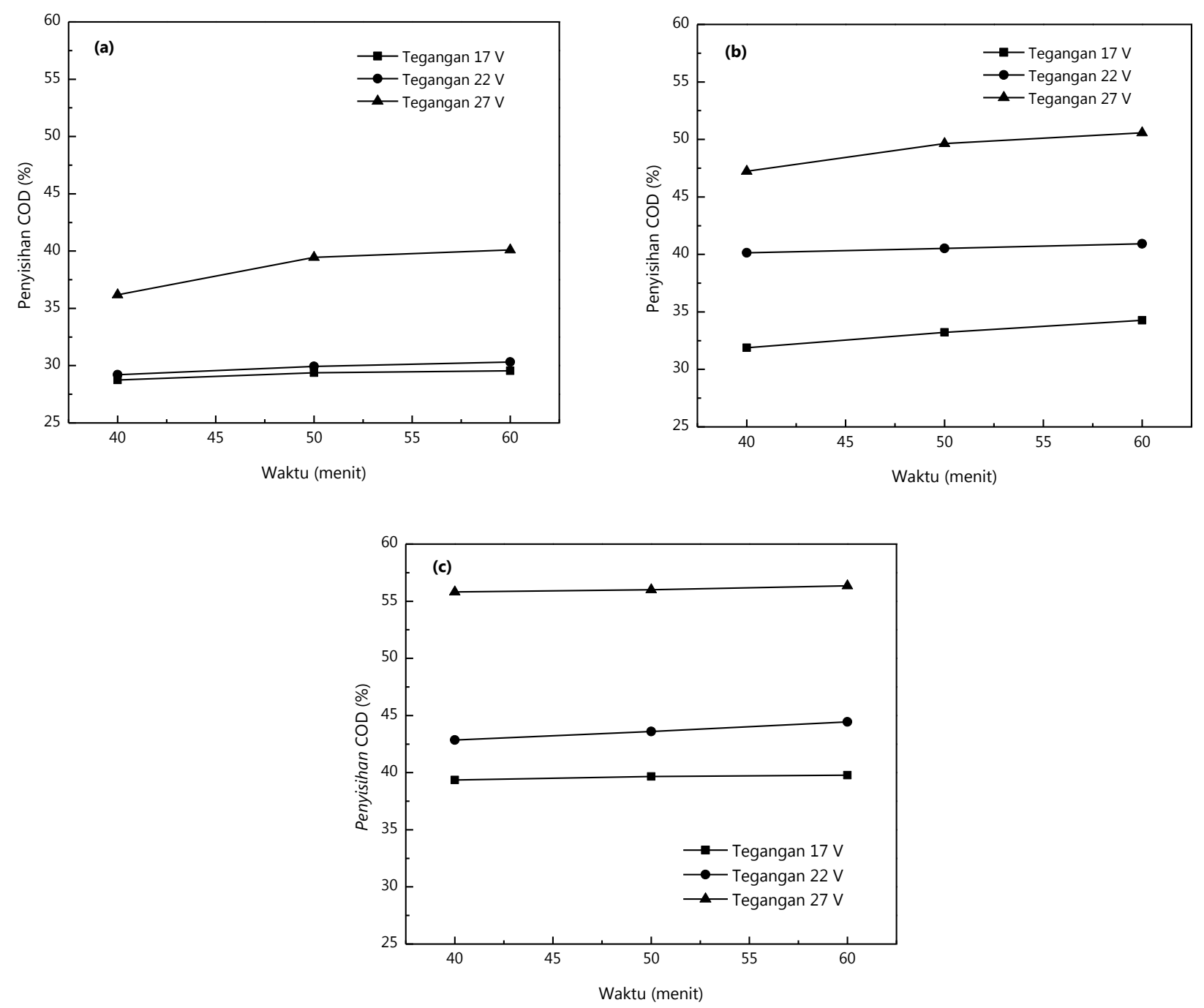

Gambar 4. Pengaruh waktu dan tegangan terhadap penyisihan $\mathrm{COD}$ (a) $\mathrm{pH} 5$ (b) $\mathrm{pH} 7$ dan $\mathrm{pH} 9$

Gambar 4 menunjukkan pengaruh waktu kontak dan tegangan terhadap efisiensi penyisihan parameter COD pada proses elektrokoagulasi. Hasil penelitian menunjukkan bahwa peningkatan waktu kontak dalam proses elektrokoagulasi menyebabkan peningkatan efisiensi penyisihan COD. Peningkatan waktu kontak menyebabkan jumlah logam aluminium yang teroksidasi membentuk ion $\mathrm{Al}^{3+}$ semakin meningkat. Proses pembentukan koagulan $\mathrm{Al}^{3+}$ melalui proses oksidasi sebagaimana telah dijelaskan pada persamaan reaksi kimia (3) sampai dengan (8). Ion $\mathrm{Al}^{3+}$ yang terlarut mengarah pada pembentukan flok $\mathrm{Al}(\mathrm{OH})_{3}$ yang mampu mengadsorpsi senyawa organik dan menangkap partikel koloid sehingga lebih mudah untuk dipisahkan. Berkurangnya kandungan senyawa organik dan partikel koloid menyebabkan kandungan COD menurun (Bratby, 2016).

Efisiensi penyisihan COD pada proses elektrokoagulasi dipengaruhi oleh tegangan operasi. Hasil penelitian sebagaimana pada Gambar 4 menunjukkan bahwa peningkatan tegangan cenderung meningkatkan efisiensi penyisihan COD di dalam air limbah. Kenaikan tegangan menyebabkan kuat arus listrik semakin tinggi sehingga rapat kuat arus akan meningkat. Hal ini menyebabkan jumlah Al yang teroksidasi menjadi $\mathrm{Al}^{3+}$ dan sweep coagulation akan semakin tinggi (Das dan Nandi, 2018). Selain itu, proses reduksi $\mathrm{H}_{2} \mathrm{O}$ pada katoda aluminium menghasilkan gelembung $\mathrm{H}_{2}$ yang dapat mereduksi material organik. Sebagian molekul organik yang terdapat pada limbah ditangkap 
$\mathrm{Al}(\mathrm{OH})_{3}$ kemudian penyisihan oleh $\mathrm{H}_{2}$ sebagai senyawa organik membentuk gelembung yang dapat menurunkan COD (Safari et al., 2016)

Faktor $\mathrm{pH}$ larutan berpengaruh terhadap efiensi penyisihan COD. Peningkatan $\mathrm{pH}$ dari 5-9 menyebabkan jumlah $\mathrm{COD}$ yang tersisihkan semakin besar. Sebagaimana telah dijelaskan sebelumnya pada penyisihan fluoride yang menunjukkan bahwa pada $\mathrm{pH}$ basa keberadaan ion hidroksida dapat memacu pembentukan sweep flocs $\mathrm{Al}(\mathrm{OH})_{3}$ yang dapat mengikat komponen COD (Doggaz et al., 2018). Hasil penelitian pada Gambar 3 menunjukkan bahwa kondisi waktu kontak 60 menit, tegangan $27 \mathrm{~V}$ dan $\mathrm{pH} 9$ menghasilkan efisiensi penyisihan COD tertinggi dibandingkan dengan kondisi lainnya yaitu mencapai $56,35 \%$.

Hasil penelitian menggunakan kombinasi presipitasi dan elektrokoagulasi diperoleh penyisihan tertinggi untuk parameter fluoride dan COD pada kondisi waktu kontak 60 menit, tegangan $27 \mathrm{~V}$, dan $\mathrm{pH} 9$ dengan nilai masingmasing sebesar $99,84 \%$ dan $56,35 \%$. Penelitian yang serupa telah dilakukan beberapa peneliti dalam menyisihkan parameter fluoride. Das dan Nandi (2020) menggunakan metode elektrokoagulasi untuk menurunkan parameter fluoride di dalam air minum dengan konsentrasi awal fluoride $10 \mathrm{mg} / \mathrm{L}$. Efisiensi optimum diperoleh pada kondisi waktu 60 menit, $\mathrm{pH} 7$, dan rapat arus $4,31 \mathrm{~mA} / \mathrm{cm}^{2}$ dengan nilai sebesar $96 \%$. Emamjomeh et al. (2011) melakukan elektrokoagulasi flotasi untuk mengolah kandungan fluoride di dalam air limbah. Efisiensi penyisihan tertinggi untuk fluoride diperoleh pada kondisi konsentrasi awal $10 \mathrm{mg} / \mathrm{L}$, waktu kontak 60 menit, dan rapat arus $18,75 \mathrm{~A} / \mathrm{m}^{2}$. Drouiche et al. (2012) melakukan pengolahan air limbah fluoride industri photovoltaic dari hasil presipitasi $\mathrm{Ca}(\mathrm{OH})_{2}$ mengunakan proses elektrokoagulasi. Proses tersebut menggunakan elektroda besi serta konsentrasi awal fluoride sebesar $25 \mathrm{mg} / \mathrm{L}$. Hasil optimum diperoleh pada kondisi tegangan 40, waktu 40 menit, serta $\mathrm{pH} 6$ dengan efisiensi penyisihan $44 \%$.

\section{KESIMPULAN}

Industri asam fosfat menghasilkan air limbah yang komponen organik COD serta fluoride dengan konsentrasi tinggi sehingga berpotensi menimbulkan pencemaran lingkungan. Pengolahan air limbah industri fosfat menggunakan kombinasi presipitasi $\mathrm{Ca}(\mathrm{OH})_{2}$ dan elektrokoagulasi merupakan metode yang efektif dalam menurunkan kandungan fluoride dan COD di dalam air limbah. Hasil penelitian menunjukkan bahwa peningkatan $\mathrm{pH}$ meningkatkan efisiensi penyisihan pada proses presipitasi. Peningkatan nilai tegangan listrik dan waktu kontak menyebabkan peningkatan efisiensi penyisihan COD dan fluoride. Efisiensi tertinggi pada proses penyisihan fluoride dan COD menggunakan presipitasi dan elektrokoagulasi diperoleh pada kondisi pH 9, waktu kontak 60 menit dan tegangan 27 volt dengan nilai efisiensi penyisihan fluoride sebesar $99,84 \%$ dan efisiensi penyisihan COD sebesar $56,35 \%$.

\section{DAFTAR PUSTAKA}

Atia, D., \& Hoggui, A., 2013, Fluoride reduction from water by precipitation with calcium chloride and lime. Journal of Fundamental Applied Science, 5(2): 129-136

Bratby, J., 2016, Coagulation and Flocculation in Water and Wastewater Treatment, Ed. $3^{\text {rd }}$, IWA Publishing, London.

BSN (Badan Standardisasi Nasional), 2004, Standard Nasional Indonesia, SNI 066989.11-2004. Cara Uji derajat keasaman $(\mathrm{pH})$ dengan menggunakan alat $\mathrm{pH}$ meter, Jakarta, Indonesia: BSN

BSN (Badan Standardisasi Nasional), 2005, Standard Nasional Indonesia, SNI 066989.29-2005. Cara Uji Fluorida Secara Spektrofotometri dengan SPADNS, Jakarta, Indonesia: BSN

BSN (Badan Standardisasi Nasional), 2009, Standard Nasional Indonesia, SNI 6989.73:2009. Cara Uji COD dengan Refluks Tertutup, Jakarta, Indonesia: BSN

Budyanto, S., Kuo, Y.-L., \& Liu, J.C., 2015, Adsorption and Precipitation of Fluoride on Calcite Nanoparticles: A Spectroscopic Study. Separation and Purifcation Technology, 150: 325-331.

Changmai, M., Pasawan, M., \& Purkait, M.K., 2018, A Hybrid Method for The Removal of Fluoride from Drinking Water: Parametric Study and 
Cost Estimation, Separation and Purification Technology, 206: 140-148

Das, D., \& Nandi B.K., 2018, Defluoridization of Drinking Water by Electrocoagulation (EC): Process Optimization and Kinetic Study, Journal of Dispersion Science and Technology, 40: 1136-1146.

Das, D., \& Nandi, B.K., 2020, Simultaneous Removal of Fluoride and $\mathrm{Fe}(\mathrm{II})$ Ions From Drinking Water by Electrocoagulation, Journal of Environmental Chemical Engineering, 8(1): 103643.

Doggaz, A., Attour, A., Mostefa, M.L.P, Tlili, M., \& Lapicque, F., 2018, Iron Removal from Waters by Electrocoagulation: Investigations of The Various Physicochemical Phenomena Involved, Separation and Purification Technology, 203: 217-225.

Drouiche, N., Aoudj, S., Lounici, H., M.Drouiche, Ouslimane, T., \& Ghaffour, N., 2012, Fluoride Removal from pretreated Photovoltaic Wastewater by Electrocoagulation: An Investigation of The Effect of Operational Parameters, Procedia Engineering, 33(2012), 385-391

Emamjomeh, M.M., Sivakumar, M., \& Varyani, A.S., 2011, Analysis and The Understanding of Fluoride Removal Mechanisms by an Electrocoagulation/Flotation (ECF) Process, Desalination, 275: 102-106

Ezzeddine, A., Bedoui, A.A., Hannachi, A., \& Bensalah, N., 2014, Removal of Fluoride from Aluminum Fluoride Manufacturing Wastewater by Precipitation and Adsorption Processes, Desalination and Water Treatment, 54: 2280-2292.

Huang, H., Liu, J., Zhang, P., Zhang, D., \& Gao, F., 2016, Investigation on The Simultaneous Removal of Fluoride, Ammonia Nitrogen and Phosphate From Semiconductor Wastewater
Using Chemical Precipitation, Chemical Engineering Journal, 307: 696-706

Nawghare, P., Rao, N.N., Bejankiwar, R., Szyprkowicz, L., \& Kaul, S.N., 2001, Treatment of Phosphoric Acid Plant Wastewater Using Fenton's Reagent and Coagulants, Journal of Environmental Science and Health, Part A: Toxic/Hazardous Substances and Environmental Engineering, A36(10): 2011-2026

Safari, S., Aghdam, M. A., \& Kariminia, H.R., 2016, Electrocoagulation for $C O D$ and diesel removal from oily wastewater, International Journal of Science and Technology, 13: 231-242

Silva, J. F.A., Graca, N.S., Ribeiro, A.M., \& Rodrigies, A.E., 2018, Electrocoagulation Process for The Removal of Co-existent Fluoride, Arsenic and Iron from Contaminated Drinking Water, Separation and Purification Technology, 197: 237-243

Tang, W., Kovalsky, P., Cao, B., \& Waite, T.D., 2016, Investigation of Fluoride Removal from LowSalinity Groundwater by Single-Pass Constant-Voltage Capacitive Deionization, Water Research, 99: 112-121.

Toyoda, A., \& Taira, T., 2000, A New Method for Treating Fluorine Wastewater to Reduce Sludge and Running Costs. IEEE Transactions on Semiconductor Manufacturing, 13(3): 305309

Wang, L., Zhang, Y., Sun, N., Sun, W., Hu, Y., \& Tang, H., 2019, Precipitation Methods Using Calcium-Containing Ores for Fluoride Removal in Wastewater, Minerals, 9(9): 1-12

Zeng, G., Ling, B., Li, Z., Luo, S., Sui, X., \& Guan, Q., 2019, Fluorine Removal and Calcium Fluoride Recovery from Rare-Earth Smelting Wastewater Using Fluidized Bed Crystallization Process. Journal of Hazardous Materials, 373: 313-320 